\title{
Phenylephrine for Blood Pressure Control in Elective Cesarean Section: Therapeutic versus Prophylactic Doses
}

\author{
José Francisco Nunes Pereira das Neves, TSA ${ }^{1}$, Giovani Alves Monteiro, TSA 2, João Rosa de Almeida ${ }^{3}$, \\ Roberto Silva Sant'Anna ${ }^{3}$, Hellen Bedim Bonin ${ }^{4}$, Carlos Furtado Macedo ${ }^{4}$
}

\begin{abstract}
Summary: Neves JFNP, Monteiro GA, Almeida JR, Sant'Anna RS, Bonin HB, Macedo CF - Phenylephrine for Blood Pressure Control in Elective Cesarean Sections: Therapeutic versus Prophylactic Doses.

Background and objectives: Spinal block is commonly used in cesarean sections and, if some prophylactic measures are not taken, the incidence of hypotension is higher than $80 \%$. The objective of this study was to compare the efficacy of the administration of therapeutic or prophylactic doses of phenylephrine to maintain blood pressure in patients undergoing spinal block for elective cesarean section.
\end{abstract}

Methods: One hundred and twenty gravidas undergoing elective cesarean sections under spinal block, randomly divided in three equal groups according to the regimen of phenylephrine administered, were included in this study. In Group 1, continuous infusion of phenylephrine, using an infusion pump at $0.15 \mu \mathrm{g} \cdot \mathrm{kg}^{-1} \cdot \mathrm{min}^{-1}$ was administered after the spinal block. In Group 2, a single dose of prophylactic phenylephrine $50 \mu \mathrm{g}$ was administered after the spinal block, and Group 3 received a single dose of phenylephrine $50 \mu \mathrm{g}$ in case of hypotension, which was defined as a drop in SBP and/or DBP of up to $20 \%$ of baseline levels. The incidence of hypotension, nausea, and vomiting as well as the Apgar score were evaluated.

Results: The incidence of hypotension was significantly greater in Group 3, affecting 85\% of the gravidas. In Groups 1 and 2 hypotension was seen in $17.5 \%$ and $32.5 \%$ of the cases respectively $(p<0.001)$. The incidence of nausea was much higher in Group 3 affecting $40 \%$ of the patients while in Groups 1 and 2 it was $10 \%$ and $15 \%$ respectively which was statistically significant.

Conclusions: According to the methodology used, this study showed that prophylactic continuous infusion of phenylephrine initiated immediately after the spinal block for cesarean section is more effective in reducing the incidence of hypotension and maternal and fetal side effects.

Keywords: ANESTHESIA, Obstetric; COMPLICATIONS: hypotension; DRUGS: phenylephrine; SURGERY, Obstetric: cesarean section.

\section{INTRODUCTION}

Spinal block is commonly used in cesarean sections due to the fast onset of action, sensorial and motor blockade, as well as a reduction in the risk of toxicity of the local anesthetic. Maternal hypotension is the most common intraoperative complication of this anesthetic technique, with an incidence higher than $80 \%$ if prophylactic measures are not taken ${ }^{1-8}$.

Preventive measures include the administration of fluids, correct positioning of the patient with decompression of abdominal vessels, and the use of vasopressors ${ }^{3-5,9}$. The use of

Received from Hospital Monte Sinai, aggregate of CET/SBA of Universidade Federal de Juiz de Fora, MG

1. Co-responsible for CET/SBA of Universidade Federal de Juiz de Fora. Coordinator of the Anesthesiology Department of Hospital Monte Sinai, Juiz de Fora, MG.

2. Co-responsible for CET/SBA da Universidade Federal de Juiz de Fora. Anesthesiologist of Hospital Monte Sinai, Juiz de Fora, MG.

3. Anesthesiologist of Hospital Monte Sinai, Juiz de Fora, MG.

4. R-III of CET/SBA da Universidade Federal de Juiz de Fora, MG.

Submitted on November 9, 2009

Approved on March 24, 2010

Correspondence to:

Dra. Hellen Bedim Bonin

Rua Vicente Beghelli, 315

Dom Bosco

36025-550 - Juiz de Fora, MG

E-mail: helennbonin@hotmail.com prophylactic vasopressors immediately after the spinal block seems to be more effective in reducing the incidence of hypotension ${ }^{10}$.

Historically, ephedrine was the vasopressor recommended in obstetrics, but evidence suggest that ephedrine causes a reduction in fetal $\mathrm{pH}$ and base excess, although without affecting the Apgar index, when compared to other vasopressors such as phenylephrine and metaraminol 8,11 .

The objective of the present study was to investigate the efficacy of phenylephrine when administered therapeutically and prophylactically for the maintenance of blood pressure in patients undergoing spinal block for elective cesarean section.

\section{METHODS}

After approval by the Ethics on Research Committee and signing of the informed consent, 120 gravidas were selected for this prospective, randomized, double blind study.

Inclusion criteria were as follows: physical status ASA I, term pregnancy of a single fetus, and indication for elective cesarean section. Exclusion criteria were: refusal of the patient to participate in the study, history of hypertension or pregnancy-induced hypertension, cardiovascular or cerebro- 
vascular disease, fetal abnormalities, history of hypersensitivity to the drugs used in the study, and contraindications to spinal block. Patients were monitored with continuous electrocardiogram, non-invasive blood pressure, and pulse oximeter using a DX 2010 monitoring device. Venoclysis was performed with an $18 \mathrm{G}$ catheter. Patients were placed in dorsal decubitus dislocating the uterus to the left for a few minutes, with blood pressure and heart rate recorded three times, with a three-minute interval between measurements to obtain mean baseline levels. With the patient in the sitting position, spinal block was performed with a 27G Quincke needle in the $L_{3}$ $\mathrm{L}_{4}$ space, and a solution containing $10 \mathrm{mg}$ of hyperbaric $0.5 \%$ bupivacaine and $100 \mu \mathrm{g}$ of morphine, at a rate of $1 \mathrm{~mL}$ every 15 seconds, was administered. Afterwards, with the patient in dorsal decubitus, a pad was placed under the right flank to dislocate the uterus to the left, and the infusion of Ringer's lactate at a rate of $10 \mathrm{~mL} . \mathrm{kg}^{-1}$ was instituted. Patients were randomly distributed in three groups, using sequential sealed envelopes containing random computer-generated numbers. The result of the distribution was not revealed, and it was not known by patients or physicians responsible for collection and analysis of the data. The size of the study population was based on prior studies. The groups were composed of 40 patients each. Phenylephrine was used in three different administration regimens:

- Group 1: Continuous intravenous infusion of phenylephrine, using a one-channel "Baxter" volumetric infusion pump, at $0.15 \mu \mathrm{g} \cdot \mathrm{kg}^{-1} \cdot \mathrm{min}^{-1}$, which was started immediately after the spinal block.

- Group 2: A single dose of phenylephrine, $50 \mu \mathrm{g} \mathrm{IV}$, administered immediately after the spinal block.

- Group 3: A single dose on phenylephrine, $50 \mu \mathrm{g} \mathrm{IV}$, administered in case of hypotension, defined as a fall in systolic blood pressure (SBP) and/or diastolic blood pressure (DBP) of up to $20 \%$ of mean baseline levels.

In all groups, the "Baxter" volumetric infusion pump was connected. In Group 1, a solution containing $10 \mathrm{~mL}$ of NS with $10 \mathrm{mg}$ of phenylephrine $\left(100 \mu \mathrm{g} \cdot \mathrm{mL}^{-1}\right)$ was prepared; in Groups 2 and 3 , a solution containing $100 \mathrm{~mL}$ of NS was prepared. Only the anesthesiologist responsible for the anesthesia was aware of which group the patient belonged to and which medications were being administered. This anesthesiologist was not involved in data collection or analysis of the results.

In all groups, the use of a bolus of $30 \mu \mathrm{g}$ of phenylephrine IV repeated every 2 minutes, in case of a drop in blood pressure greater than $20 \%$, not controlled with the therapeutic regimen used, was allowed.

Episodes of hypotension defined as a drop in SBP and/ or DBP greater than $20 \%$ were recorded. Reactive hypertension was characterized as a blood pressure $20 \%$ greater than baseline mean levels after the use of the vasopressor. Heart rate lower than $50 \mathrm{bpm}$ characterized bradycardia, and when associated with hypotension it was treated with $0.5 \mathrm{mg}$ of atropine IV. Nausea, vomiting, and the need of rescue doses of phenylephrine were recorded.
Apgar scores in the first and fifth minutes of the newborns were evaluated.

The results obtained underwent statistical analysis using the software SPSS version 14.0. To analyze the equality of the initial anthropometric conditions, Analysis of Variance (ANOVA) followed by the Tukey Post Hoc test were used. The significance of the association among the three groups and the categorical parameters were determined by the Chisquare test. The Kruskal-Wallis test followed by the MannWhitney test was used to determine the significance of the differences in Apgar scores among the three groups. Levels of $p<0.05$ were considered significant.

\section{RESULTS}

Statistical differences in age, weight, height, initial systolic blood pressure (SBP), and initial heart rate (HR) were not observed among the three groups, and although a statistically significant difference was observed in initial diastolic blood pressure (DBP) $(p<0.05)$ among the three groups it was not clinically relevant (Table I).

As for hypotension, it was observed in $17.5 \%$ of the cases in Group 1, and in 32.5\% in Group 2. The incidence of hypotension was much higher in Group 3 than in Groups 1 and 2, affecting $85 \%$ of the patients, which was statistically significant $(p<0.001)$.

The number of patients who required rescue doses of phenylephrine was also statistically significant among the groups ( $p<0.01$ ), affecting $12.5 \%$ of the patients in Group 1, $30 \%$ in Group 2, and $70 \%$ in Group 3.

Only one patient in Group 1 developed reactive hypertension, which was adequately treated with discontinuation of the infusion of phenylephrine. Bradycardia was seen in one patient in Group 2, which did not require treatment, since it was transitory and it was not associated with hypotension.

The incidence of nausea was greater in Group 3, affecting $40 \%$ of the patients, while in Groups 1 and 2 it had an incidence of $10 \%$ and $15 \%$, respectively, which was statistically significant $(p=0.02)$. Statistically significant differences in the incidence of vomiting were not observed among the groups (Table II, Chart 1).

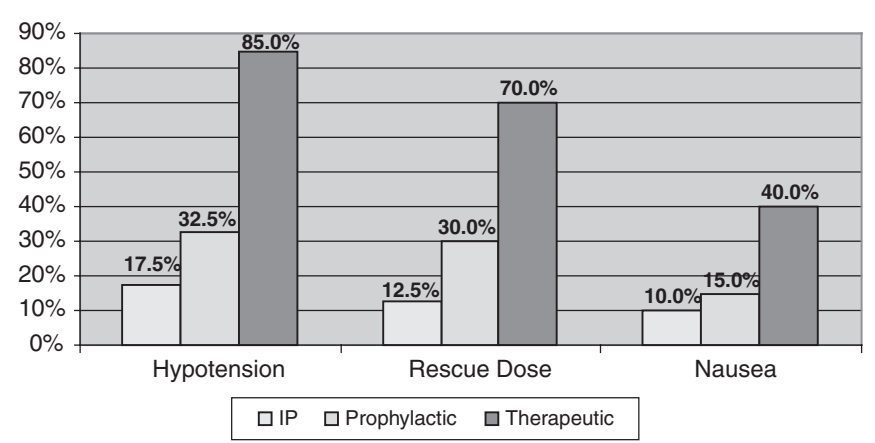

Chart 1 - Intraoperative Parameters. 
Table I - Preoperative Parameters

\begin{tabular}{lllll}
\hline & Group 1 & Group 2 & Group 3 & $p$ \\
\hline Age & $30.78 \pm 5.93$ & $29.8 \pm 6.06$ & $29.3 \pm 5.45$ & 0.517 \\
Weight & $74.03 \pm 8.34$ & $74.63 \pm 9.22$ & $76.45 \pm 9.52$ & 0.461 \\
Height & $162.75 \pm 4.31$ & $162.58 \pm 4.82$ & $162.83 \pm 4.56$ & 0.969 \\
Initial SBP & $120.45 \pm 9.79$ & $119.98 \pm 10.05$ & $123.33 \pm 9.77$ & 0.264 \\
Initial DBP & $70.05 \pm 9.36$ & $74.5 \pm 8.60$ & $75.65 \pm 5.02$ & 0.005 \\
HR & $87.9 \pm 12.14$ & $86.45 \pm 13.51$ & $84.33 \pm 11.41$ & 0.433 \\
\hline
\end{tabular}

Values expressed as mean \pm standard deviation; ANOVA test; Post Hoc

Group 1 - continuous infusion of phenylephrine in infusion pump; Group 2 - single prophylactic dose of phenylephrine after spinal block; Group 3 - single dose of phenylephrine; SBP - systolic blood pressure; DBP - diastolic blood pressure; HR - heart rate.

Table II - Intraoperative Parameters

\begin{tabular}{lllll}
\hline & Group 1 & Group 2 & Group 3 & p \\
\hline Hypotension & $17.5 \%$ & $32.5 \%$ & $85 \%$ & $<0.001$ \\
Nausea & $10 \%$ & $15 \%$ & $40 \%$ & 0.002 \\
Vomiting & $0 \%$ & $7.5 \%$ & $12.5 \%$ & 0.079 \\
Rescue dose & $12.5 \%$ & $30 \%$ & $70 \%$ & $<0.001$ \\
\hline
\end{tabular}

Values expressed as percentage of cases; Chi-square test

Group 1 - continuous infusion of phenylephrine in infusion pump; Group 2 - single prophylactic dose of phenylephrine after spinal block; Group 3 - single dose of phenylephrine.

Table III - Evaluation of the Newborns (Apgar Scores)

\begin{tabular}{|c|c|c|c|c|c|c|}
\hline \multirow{2}{*}{ Apgar } & \multicolumn{2}{|l|}{ Group 1} & \multicolumn{2}{|l|}{ Group 2} & \multicolumn{2}{|l|}{ Group 3} \\
\hline & $1^{\text {st }} \min$ & $5^{\text {th }} \min$ & $1^{\text {st }} \min$ & $5^{\text {th }} \min$ & $1^{\mathrm{st}} \min$ & $5^{\text {th }} \min$ \\
\hline 7 & 0 & 0 & 0 & 0 & 5 & 0 \\
\hline 8 & 4 & 0 & 7 & 0 & 11 & 0 \\
\hline 10 & 4 & 36 & 1 & 35 & 0 & 30 \\
\hline
\end{tabular}

Kruskal-Wallis test; Mann-Whitney test.

Apgar scores in the first minute showed a higher proportion of newborns with values equal to or lower than 8 in Group $3(40 \%)$ than in Groups 1 and 2, which was statistically significant $(p=0.01)$. A statistically significant difference in the Apgar in the first minute was not observed between Groups 1 and 2. The Apgar in the fifth minute did not show differences among the three groups (Table III).

\section{DISCUSSION}

Hypotension after spinal block for cesarean section is a common clinical problem, with an increase in maternal and fetal morbidity ${ }^{1,2,5,9}$.

The sympathetic blockade causes a reduction in blood pressure as a result of the fall in systemic vascular resistance with a reduction in venous return leading to a fall in cardiac output and occasionally heart rate ${ }^{5}$.

The fall in blood pressure has immediate maternal and fetal repercussions. Maternal symptoms include nausea, vomiting, and feeling of impending doom due to a reduction in cerebral reperfusion, and inadequate treatment of hypotension can lead to loss of consciousness and cardiac arrest. The fetus is affected immediately because uterine flow depends on maternal blood pressure ${ }^{2}$.
An isolated method that prevents hypotension during cesarean section does not exist ${ }^{12}$. The use of crystalloids before spinal block is practically ineffective because, despite the previous volume expansion, $85 \%$ of the patients develop hypotension. This happens because crystalloids are rapidly redistributed and induce the secretion of natriuretic peptide, leading to peripheral vasodilation and extravasation of fluid to the third space ${ }^{9}$. Administration after the spinal block can be useful because it increases the intravascular fluid during the period of maximal risk of hypotension and facilitates the rapid circulation of the vasopressor ${ }^{2}$.

It is important to fully understand the hemodynamic responses to choose properly the vasopressor and clinical dose ${ }^{14}$. The ideal vasopressor should have a low cost, be readily available, have a fast onset of action, be reliable, and have favorable effects in maternal heart rate, fetus, and placental perfu$s^{2}{ }^{2}$. Phenylephrine is considered the first drug of choice and its efficacy and safety during cesarean sections have been thoroughly investigated ${ }^{12}$. This is a synthetic non-catecholamine drug, but its function is similar to that of norepinephrine with direct action in the $]_{1}$-adrenergic receptor ${ }^{2}$. It promotes vasoconstriction especially arterial by increasing systemic vascular resistance, and therefore increasing preload ${ }^{2,14}$.

In the present study, the doses chosen were the minimal for direct intravenous administration (50 to $200 \mu \mathrm{g}$ ) and conti- 
nuous infusion $\left(0.15 \text { to } 0.75 \mu \mathrm{g} \cdot \mathrm{kg}^{-1} \cdot \mathrm{min}^{-1}\right)^{15}$, while the optimal dose has yet to be determined ${ }^{1}$. The rescue dose $(30 \mu \mathrm{g})$ was the same used in another study ${ }^{12}$.

The group that received conventional phenylephrine showed an incidence of hypotension of $85 \%$. In the groups in which the drug was used prophylactically, the incidence of hypotension, collateral effects, and the need of rescue doses were lower. The best results were seen in the continuous infusion group.

The optimal dose of phenylephrine for the control of blood pressure during cesarean section has not been determined yet. It has been observed that, even when phenylephrine was used in high doses (above 2,000 $\mu \mathrm{g}$ ), fetal deleterious effects measured by the Apgar score and arterial blood gases of umbilical cord blood were not observed ${ }^{5,8}$. This occurs because the contractile response of the uterine artery to drugs, such as ephedrine and phenylephrine, is attenuated during pregnancy due to an increase in the activity of nitrous oxide ${ }^{16}$. Low $\mathrm{pH}$ and base excess are related with the time between the surgical incision and fetal extraction ${ }^{8}$.

As for collateral effects, a higher incidence of nausea and vomiting was seen in the therapeutic group. Although seve- ral factors are related to the etiology of nausea and vomiting during cesarean section under regional block, hypotension is the most important, especially before delivery. Nausea and vomiting have an incidence of $4 \%$ in patients in whom systolic pressure is maintained at baseline levels, and it ranges from 16 to $40 \%$ in patients whose blood pressure is lower than or equal to 80 to $90 \%$ of pre-anesthetic levels 1 .

Evaluation of Apgar scores in the first minute showed a significant statistical difference between the therapeutic and prophylactic groups, which emphasizes the importance of monitoring blood pressure for maintenance of uteroplacental perfusion. In the present study, we decided not to performed analysis of umbilical cord blood gases because the difference of time between blood collection and analysis can change values and influence the results, and low $\mathrm{pH}$ levels and base excess are related with the time between the surgical incision and fetal extraction ${ }^{8}$.

According to the methodology used, the study shows that continuous infusion of prophylactic phenylephrine initiated immediately after the spinal block is more effective in reducing the incidence of hypotension and maternal and fetal side effects. 
09. Siddik-Sayyid SM, Nasr VG, Taha SK et al. - A randomized trial comparing colloid preload to coload during spinal anesthesia for elective cesarean delivery. Anesth Analg, 2009;109:1219-1224.

10. Ngan Kee WD, Khaw KS, Ng FF et al. - Prophylactic phenylephrine infusion for preventing hypotension during spinal anesthesia for cesarean delivery. Anesth Analg, 2004;98:815-821.

11. Ngan Kee WD, Khaw KS, Tan PE et al. - Placental transfer and fetal metabolic effects of phenylephrine and ephedrine during spinal anesthesia for cesarean delivery. Anesthesiology, 2009;111:506-512.

12. Langesaeter E, Rosseland LA, Stubhaug A - Continuous invasive blood pressure and cardiac output monitoring during cesarean delivery: a randomized, double-blind comparison of low-dose versus highdose spinal anesthesia with intravenous phenylephrine or placebo infusion. Anesthesiology, 2008;109:856-863.

13. Ngan Kee WD, Tam YH, Khaw KS et al. - Closed-loop feedback computer-controlled infusion of phenylephrine for maintaining blood pressure during spinal anaesthesia for caesarean section: a preliminary descriptive study. Anaesthesia, 2007;62:1251-1256.

14. Dyer RA, Reed AR, van Dyk D et al. - Hemodynamic effects of ephedrine, phenylephrine, and the coadministration of phenylephrine with oxytocin during spinal anesthesia for elective cesarean delivery. Anesthesiology, 2009;111:753-765.

15. Slullitel A - Vasopressores. em: Cangiani LM, Posso IP, Potério GMB et al. - Tratado de Anestesiologia SAESP, 6 Ed, São Paulo, Atheneu, 2006;655-666.

16. Erkinaro T, Kavasmaa T, Pakkila $M$ et al. - Ephedrine and phenylephrine for the treatment of maternal hypotension in a chronic sheep model of increased placental vascular resistance. $\mathrm{Br} \mathrm{J}$ Anaesth, 2006;96:231-237.

Resumen: Neves JFNP, Monteiro GA, Almeida JR, Sant'Anna RS, Bonin HB, Macedo CF - Utilización de la Fenilefrina para el Control de la Presión Arterial en Cesáreas Electivas: Dosis Terapéutica versus Profiláctica.

Justificativa y objetivos: La raquianestesia se usa a menudo en casos de cesárea y si algunas medidas profilácticas no se adoptan, la incidencia de hipotensión arterial es superior al $80 \%$. El objetivo de este estudio fue comparar la eficacia de la fenilefrina cuando se administra terapéutica o profilácticamente para el mantenimiento de la presión arterial en pacientes sometidas a la raquianestesia para cesáreas electivas.

\section{REFERÊNCIAS / REFERENCES}

01. Tanaka M, Balki M, Parkes RK et al. - ED95 of phenylephrine to prevent spinal-induced hypotension and/or nausea at elective cesarean delivery. Int J Obstet Anesth, 2009;18:125-130.

02. Macarthur A, Riley ET - Obstetric anesthesia controversies: vasopressor choice for postspinal hypotension during cesarean delivery. Int Anesthesiol Clin, 2007;45:115-132.

03. Saravanan S, Kocarev M, Wilson RC et al. - Equivalent dose of ephedrine and phenylephrine in the prevention of post-spinal hypotension in Caesarean section. Br J Anaesth, 2006;96:95-99.

04. Hennebry MC, Stocks GM, Belavadi P et al. - Effect of i.v phenylephrine or ephedrine on the ED50 of intrathecal bupivacaine with fentanyl for Caesarean section. Br J Anaesth, 2009;102:806-811.

05. Ngan Kee WD, Khaw KS - Vasopressors in obstetrics: what should we be using? Curr Opin Anaesthesiol, 2006;19:238-243.

06. Prakash S, Pramanik V, Chellani $\mathrm{H}$ et al. - Maternal and neonatal effects of bolus administration of ephedrine and phenylephrine during spinal anaesthesia for caesarean delivery: a randomized study. Int $\mathrm{J}$ Obstet Anesth, 2010;19:24-30.

07. Loughrey JPR, Yao N, Datta S et al. - Hemodynamic effects of spinal anesthesia and simultaneous intravenous bolus of combined phenylephrine and ephedrine versus ephedrine for cesarean delivery. Int J Obstet Anesth, 2005;14:43-47.

08. Magalhães E, Govêia CS, Ladeira LCA et al. - Efedrina versus fenilefrina: prevenção de hipotensão arterial durante anestesia raquídea para cesariana e efeitos sobre o feto. Rev Bras Anestesiol, 2009;59:11-20.

Método: Se estudiaron 120 gestantes sometidas a cesáreas electivas bajo raquianestesia, ubicadas aleatoriamente en tres grupos iguales, conforme al régimen de administración de fenilefrina. En el Grupo 1, se administró fenilefrina en infusión continua, con bomba de infusión en dosis de $0,15 \mu \mathrm{g} \cdot \mathrm{Kg}^{-1} \cdot \mathrm{min}^{-1}$ después de la raquianestesia. En el Grupo 2, fue administrada fenilefrina en dosis única, de forma profiláctica, en dosis de $50 \mu \mathrm{g}$ después de la raquianestesia, y en el Grupo 3, fenilefrina en dosis única de $50 \mu \mathrm{g}$ en el caso de hipotensión arterial definida como una caída de la PAS y/o PAD en hasta un $20 \%$ con relación al promedio de los valores basales. Se evaluó la incidencia de hipotensión arterial, náuseas, vómitos y el índice de Apgar.

Resultados: La incidencia de hipotensión arterial fue significativamente más elevada en el Grupo 3, acaeciendo en un $85 \%$ de las embarazadas. En los Grupos 1 y 2, ocurrió en un $17,5 \%$ y $32,5 \%$ de los casos respectivamente $(\mathrm{p}<0,001)$. La incidencia de náuseas fue bastante superior en el Grupo 3 en un $40 \%$ de las pacientes, mientras que en los Grupos 1 y 2 la incidencia fue de un $10 \%$ y un 15\% respectivamente, presentando significancia estadística.

Conclusiones: A tono con la metodología utilizada, el estudio muestra que la infusión continua profiláctica de fenilefrina iniciada inmediatamente después de la realización de la raquianestesia para cesárea, es más efectiva en la reducción de la incidencia de hipotensión arterial y los efectos colaterales maternos y fetales. 